EXTENDED REPORT

\title{
Minimising the risk of prion transmission by contact tonometry
}

\author{
S Z Amin, L Smith, P J Luthert, M E Cheetham, R J Buckley
}

Br J Ophthalmol 2003;87:1360-1362

See end of article for authors' affiliations

......................

Correspondence to: Professor R J Buckley, 57A Wimpole Street, London WIG 8YP, UK; RJBcity@aol.com

Accepted for publication 3 March 2003

\begin{abstract}
Aims: The unknown prevalence of variant Creutzfeldt-Jakob disease (VCJD) in the UK population has led to fears of horizontal transmission through routine medical procedures. The potential risk of transmission via contact tonometry was examined.

Methods: The total amount of protein carried over by tonometer tips after applanation of patients was assessed.

Results: Tonometer tips had an inherent ability to carry proteinaceous material. There was a large variability in the load carried over between individual patients. Rinsing tonometer tips in water reduced protein carryover. Wiping the tonometer tips also reduced carriage, though less dramatically.

Conclusion: There is a small theoretical risk of transmission of vCJD by contact tonometry through reuse, but this should be reduced if the prisms are washed and wiped. In the light of these findings a protocol for the management of reusable tonometer prisms is recommended.
\end{abstract}

$\mathrm{T}$ he transmissible spongiform encephalopathies are a group of neurodegenerative disorders, which include bovine spongiform encephalopathy (BSE) in cattle, scrapie in sheep, and Creutzfeldt-Jakob disease (CJD) in humans. These diseases are associated with abnormal conformers of a normal glycoprotein, PrP. These abnormal conformations of PrP, known as prions, possess enhanced resistance to proteases and are termed $\mathrm{PrP}^{\mathrm{Sc}}$ or $\operatorname{PrP}^{\mathrm{Res}}{ }^{1}$

Since 1985, the UK population has been at risk of exposure to the transmissible agent responsible for BSE in cattle following its entry into the human food chain. In humans, disease thought to arise from this route of transmission has been termed "variant CJD" (vCJD), ${ }^{2}$ to distinguish it from classic CJD. ${ }^{3}$

It is conceivable that substantial numbers of the population may be incubating $\mathrm{vCJD}^{3}$ and the possibility of iatrogenic transmission via contaminated surgical or other invasive instruments remains a major concern, as prions resist normal cleaning and sterilisation procedures. ${ }^{4}$ This has been shown in $\mathrm{CJD}^{5-7}$ where neurosurgical techniques using contaminated instruments and materials have resulted in transmission of the disease.

In ophthalmology, the gold standard for intraocular pressure measurement remains the Goldmann tonometer. The routine examination of most patients, at most institutions including Moorfields Eye Hospital (MEH), involves assessment of intraocular pressure by contact tonometry, unless there is a contraindication. It is well known that some diseases-for example, adenovirus keratoconjunctivitis, can be unintentionally transmitted during this investigation. The possible risk of horizontal transmission of vCJD via contact tonometry has therefore given cause for concern. ${ }^{8}$ To partially address these concerns, the Spongiform Encephalopathy Advisory Committee (SEAC) issued a press release on 26 July 2001 declaring the importance of applying best decontamination procedures to the re-use of rigid trial set contact lenses and ophthalmic devices. ${ }^{9}$ These include the use of a solution of sodium hypochlorite containing $20000 \mathrm{ppm}$ of available chlorine. Ophthalmic devices include tonometer prisms, diagnostic contact lenses such as gonioscopes, and biometry probes. Most of these have not been shown to be capable of withstanding such treatment. Currently at $\mathrm{MEH}$, tonometer prisms are disinfected in $1000 \mathrm{ppm}$ sodium hypochlorite for 5 minutes, a concentration and time that have not been shown to remove prion infectivity. Higher concentrations of sodium hypochlorite used for 1 hour ${ }^{10}$ may, however, cause cumulative corrosion of the prisms, ${ }^{11}$ though the manufacturer Haag-Streit permits the use of such solutions on its Goldmann prisms for up to 100 times. ${ }^{12}$ An alternative is the use of disposable tonometer tips, which may have significant cost implications in a busy clinical setting.

We set out to assess the potential risk for horizontal transmission by contact tonometry ${ }^{13-17}$ using reusable tonometer prisms, by measuring the amount of proteinaceous material accumulating on the contact surfaces of disposable tonometer tips. Our study aims to address the question as to whether stringent decontamination of re-usable prisms or the use of disposable tips or shields is preferable.

\section{MATERIALS AND METHODS}

We used disposable tonometer tips (Tonosafe, Clement Clarke International) made from clear acrylic plastic, using the same material and tip diameter as the standard Goldmann tonometer prism. ${ }^{18}$ Patients were enrolled in the study (Moorfields Eye Hospital institutional research and ethics approval, Project 655). Patients were routinely applanated, where appropriate, in the outpatient clinic. Either one or both eyes were applanated after instillation of a drop of $0.3 \% / 0.125 \%$ benoxinate + fluorescein mixture, using the same disposable tonometer tip. If both eyes were applanated, no decontamination procedure was carried out between eyes.

The method of decontaminating the disposable tonometer tips after applanation was varied. We used either no rinse, or soaked the tips in $1 \mathrm{ml}$ of MilliQ ultra high purity water $\left(\mathrm{uhpH}_{2} \mathrm{O}\right)$ for 5 minutes, or washed them in $50 \mathrm{ml}$ of $\mathrm{uhpH}_{2} \mathrm{O}$ for 5 minutes. Sodium hypochlorite was not used, as it interferes with protein quantitation (unpublished data). We also assessed the wiping of tonometer tips using an isopropyl alcohol swab (Steriswab, Seton Group).

The amount of protein remaining on the tonometer tips was assessed using two methods, the CBQCA protein quantitation kit (Molecular Probes), and the BCA protein quantitation kit (Pierce), in each case in accordance with the manufacturer's instructions following protein solubilisation 
with $0.1 \mathrm{M}$ sodium borate, $\mathrm{pH} 9.3$, and $3 \mathrm{M}$ guanidine $\mathrm{HCl}$ respectively. Each procedure was assessed on four used tonometer tips.

\section{RESULTS}

\section{Observations}

The tonometer tips had an inherent ability to carry a meniscus of fluid despite vigorous shaking (Fig l).

There was large patient to patient variability in the tolerance of applanation. The more trauma involved in taking the reading, the more material (for example, cellular debris, mucus, tear fluid) appeared to be carried over into the protein analysis. After protein quantification, silver staining of the tonometer heads confirmed that no residual protein remained on the tonometer head.

\section{Total protein carriage after applanation}

Analysis of the protein levels carried over on tonometer tips showed that there was a great deal of variability in the load of proteinaceous material carried over between individual patients. The lowest amount of protein detected directly from an eye was $4.3 \mu \mathrm{g}$, whereas the highest carryover, from a red and inflamed eye, was in excess of our measured upper limit of $20 \mu \mathrm{g}$ (Table 1). Rinsing the tonometer tip in $\mathrm{uhpH}_{2} \mathrm{O}$ for 5 minutes reduced protein carryover, with the greater volume producing the greater reduction (using ANOVA, $\mathrm{p}=0.259$ ). Wiping the tonometer tip with an isopropyl alcohol swab tended to further reduce carryover but likewise this did not reach significance, probably because of the interpatient variation (data not shown) and the small numbers assessed.

\section{DISCUSSION}

Our data show that tonometer tips are capable of carrying proteinaceous material that could potentially be transferred from one eye to another. The amount of protein contaminating a second eye could conceivably be in the tens of micrograms $(\mu \mathrm{g})$ in the case of a first inflamed eye that tolerates applanation poorly, suggesting that this constitutes a potential route for the horizontal transmission of vCJD. A recent study, however, demonstrated that no $\operatorname{PrP}^{\mathrm{Sc}}$ could be detected in the anterior segment (lens, aqueous humour, iris, and cornea) of the eyes of vCJD or sporadic CJD patients. ${ }^{19}$ The levels of $\operatorname{PrP}^{\mathrm{Sc}}$ cannot be directly correlated with units of human infectivity, but this absence of $\mathrm{PrP}^{\mathrm{Sc}}$ suggests that levels of infectivity in the anterior segment are at least $400 \times$ lower than in brain tissue. If we assume this level of

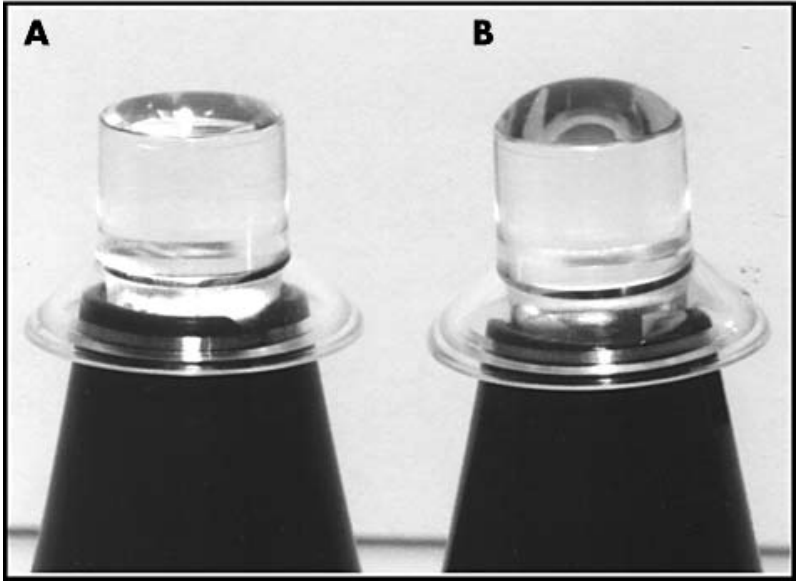

Figure 1 Disposable tonometer heads mounted on reusable holders showing variations in the volume of the fluid meniscus. (A) shows the meniscus after shaking and (B) shows the meniscus without shaking.
Table 1 Effect of rinsing tonometer tips

\begin{tabular}{llll}
\hline Volume of rinse & No & Mean (SD) & Range \\
\hline No rinse & 4 & $7.6(8.4)^{*}$ & $4.3-20>^{*}$ \\
$1 \mathrm{ml}$ & 4 & $3.7(2.2)$ & $1.3-5.9$ \\
$50 \mathrm{ml}$ & 4 & $1.9(1.7)$ & $0.8-4.4$ \\
\hline
\end{tabular}

Mean $=$ mean amount of protein present on tonometer tips $(\mu \mathrm{g})$; $\mathrm{n}=$ number of patients analysed; range $=$ minimum $/$ maximum values from the group of patients

${ }^{*} \mathrm{~A}$ reading in excess of our upper limit for measurement (that is, above $20 \mu \mathrm{g})$; for the mean reading, a value of 20 was used.

infectivity in the anterior segment, then by a worst case scenario calculation there would be less than one infectious unit (intracerebral $\mathrm{LD}_{50}$ ) per $\mu \mathrm{g}$ of total protein on the ocular surface. Therefore, there exists a small theoretical risk of transmission of prion disease by contact tonometry if tonometer prisms are reused, but this risk can be substantially reduced if the prisms are washed and disinfected.

The risk of transmission could be further reduced by using larger volumes of washes for longer periods, and adding wiping between washes. ${ }^{20}$ Regular replenishment of the wash should also be encouraged, as substantial amounts of patient derived protein could accumulate with repeated use (an estimate of up to $1 \mathrm{mg}$ after 50 successive applanations).

\section{CONCLUSION}

To completely eradicate the risk of horizontal transmission of prion protein, disposable tonometer prism tips should be used. However, if disposable tips are not used, reusable tonometer prisms should be soaked in the largest volume (at least $50 \mathrm{ml}$ ) of aqueous solution for at least 5 minutes. Consideration should also be given to the use of sodium hypochlorite at a concentration of $20000 \mathrm{ppm}$, as recommended in the guidance published by the College of Optometrists and the Association of British Dispensing Opticians. $^{21}$ The soaking container should be changed frequently, ideally between patients. In addition, the prisms should be mechanically wiped. These actions may be equally useful in the reduction of protein carryover.

\section{ACKNOWLEDGEMENTS}

Grant support: Joint Working Group on the Re-Use of Contact Lenses and Ophthalmic Devices, College of Optometrists, 42 Craven Street, London WC2N 5NG, UK.

\section{Authors' affiliations}

S Z Amin, P J Luthert, M E Cheetham, Institute of Ophthalmology, Department of Pathology, Bath Street, London ECIV 9EL, UK L Smith, R J Buckley, Moorfields Eye Hospital, City Road, London ECIV 2PD, UK

R J Buckley, Department of Optometry and Visual Science, City University, Northampton Square, London ECIV OHB, UK

\section{REFERENCES}

1 Caughey B. Interactions between prion protein isoforms: the kiss of death? Trends Biochem Sci 2001;26:235-42.

2 Hill AF, Desbruslais $M$, Joiner $S$, et al. The same prion strain causes vCJD and BSE. Nature 1997;389:448-50, 526

3 Collinge J. Variant Creutzfeldt-Jakob disease. Lancet 1999;354:317-23.

4 Brown P, Rohwer RG, Green EM, et al. Effect of chemicals, heat, and histopathologic processing on high-infectivity hamster-adapted scrapie virus. $J$ Infect Dis 1982;145:683-7.

5 Brown P, Cathala F, Raubertas RF, et al. The epidemiology of CreutzfeldtJakob disease: conclusion of a 15-year investigation in France and review of the world literature. Neurology 1987;37:895-904.

6 Lang CJ, Heckmann JG, Neundorfer B. Creutzfeldt-Jakob disease via dural and corneal transplants. J Neurol Sci 1998;160:128-39.

7 Brown P, Gibbs CJ Jr, Rodgers-Johnson P, et al. Human spongiform encephalopathy: the National Institutes of Health series of 300 cases of experimentally transmitted disease. Ann Neurol 1994;35:513-29. 
8 Davanipour Z Alter $M$, Sobel $E$, et al Creutzfeldt-Jakob disease: possible medical risk factors. Neurology 1985;35:1483-6.

9 Spongiform Encephalopathy Advisory Committee. SEAC public summary of the meeting on 27 June 2001. (www.defra.gov.uk/animalh/bse/bsescience/level-4-seac.html)

10 Taylor DM. Inactivation of BSE agent. Dev Biol Stand 1991;75:97-102.

11 Chronister CL. Structural damage to Schiotz tonometers after disinfection with solutions. Optom Vis Sci 1997;74:164-6.

12 Haag-Streit Dok Nr 92029200066 01010. Desinfektion der Haag-Streit Kontacktgläser und Tonometermesskörper, 1998.

13 Smith CA, Pepose JS. Disinfection of tonometers and contact lenses in the office setting: are current techniques adequate? Am J Ophthalmol 1999; 127:77-84.

14 Hogan RN, Brown P, Heck E, et al. Risk of prion disease transmission from ocular donor tissue transplantation. Cornea 1999;18:2-11.

15 Tullo A, Buckley R, Painter M. CJD and the eye. Eye 2000;14(Pt 3a):259-60.
16 Rutala WA, Weber DJ. Creutzfeldt-Jakob disease: recommendations for disinfection and sterilization. Clin Infect Dis 2001;32:1348-56.

17 Walia JS, Chronister CL. Possible iatrogenic transmission of Creutzfeldt-Jakob disease via tonometer tips: a review of the literature. Optometry 2001:72:649-52.

18 Desai SP, Sivakumar S, Fryers PT. Evaluation of a disposable prism for applanation tonometry. Eye 2001; 15:279-82.

19 Wadsworth JD, Joiner S, Hill AF, et al. Tissue distribution of protease resistant prion protein in variant Creutzfeldt-Jakob disease using a highly sensitive immunoblotting assay, Lancet 2001:358:171-80.

20 Threlkeld AB, Froggatt JW III, Schein OD, et al. Efficacy of a disinfectant wipe method for the removal of adenovirus 8 from tonometer tips. Ophthalmology 1993;100:1841-5.

21 College of Optometrists, Association of British Dispensing Opticians. Guidance on the re-use of contact lenses and ophthalmic devices. London, 2001.

\section{$\mathrm{ECHO}$}

\section{Gamma-D crystallin gene mutation causes autosomal dominant congenital cerulean cataracts}

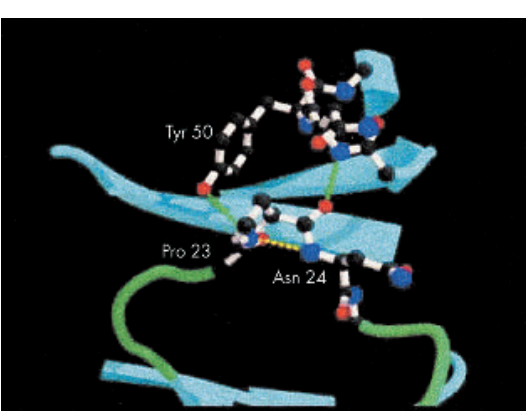

Figure 1 Schematic view of the protein fold determined by $x$ ray crystallography centred on residue P23 and looking along $\beta$-sheet 2 of the normal CRYGD protein.
Desearchers from Morocco and Paris (France) have mapped the gene responsible for autosomal dominant congenital cerulean cataract (ADCCC) by studying a family of 19 affected and 24 unaffected subjects spanning four generations.

The gene was localised to a region of chromosome 2q33-q35, spanning the $\gamma$-crystallin gene $(C R Y G)$ cluster. This is the third locus identified in ADCCC, and characterises a phenotype with early onset (diagnosable at birth) and rapid progression.

All affected members of this kindred had a $\mathrm{C}>\mathrm{A}$ transversion in exon 2 of the CRYGD gene. This class of genes encodes a superfamily of major soluble structural lens proteins. The particular transversion found results in a proline to threonine substitution at amino acid 23 in the first of the four Greek key motifs that characterise the protein. This may alter the protein folding or decrease the protein's thermodynamic stability or solubility.

A Journal of Medical Genetics 2003;40:262-267.

A Please visit the British Journal of Ophthalmology website [www.bjophthalmol.com] for a link to the full text of this article. 